\title{
IMPLIKASI YURIDISI PERKAWINAN POLIGAMI DI BAWAH TANGAN DI DESA SENGGIGI, KECAMATAN BATU LAYAR, LOMBOK BARAT, NTB
}

\author{
Wayan Resmini $1^{*}$, Abdul Sakban², Ni Putu Ade Resmayani ${ }^{3}$ \\ ${ }^{1 *}$ Program Studi Pendidikan Pancasila dan Kewarganegaraan, Universitas Muhammadiyah Mataram \\ ${ }^{2}$ Program Studi Pendidikan Pancasila dan Kewarganegaraan, Universitas Muhammadiyah Mataram \\ ${ }^{3}$ Sekolah Tinggi Pariwisata Mataram \\ Corresponding author : \\ Email: wayan resmini @ymail.com
}

Diterima 26 April 2019, Disetujui 3 Mei 2019

\begin{abstract}
ABSTRAK
Perkawinan poligami di Indonesia, dilakukan secara sembunyi-sembunyi atau di bawah tangan terutama di kalangan menengah. Di kalangan santri tradisionalis di pedesaan praktek poligami masih marak dilakukan tapi jumlahnya jauh lebih menurun daripada pada sebelumnya. Kegiatan ini bertujuan untuk memberikan pemahaman dan wawasan kepada masyarakat. Metode yang digunakan adalah penyuluhan, tanya jawab. Implikasi yuridis perkawinan poligami yang paling dirugikan adalah perempuan dan anak-anak., maka anak tersebut hanya diakui hak-haknya dari pihak ibu. Dalam pembuatan akta kelahiran, anak hanya akan dicatat mengikuti nama ibu karena catatan sipil untuk kelahiran anak mengisyaratkan adanya surat nikah resmi dari negara.Hal ini berimbas pada pembagian harta warisan, dimana sang anak akan kesulitan mendapatkan hak warisnya, isteri tidak memperoleh tunjangan apapun jikak suami meninggal, apabila suami sebagai pegawai, maka isteri tidak memperoleh tunjangan perkawinan dan tunjangan pensiun si suami.
\end{abstract}

Kata kunci: implikasi yuridis, Poligami

\section{ABSTRACT}

Polygamy marriage in Indonesia, carried out clandestinely or under the hand, especially in the middle class. Among the traditionalist santri in the countryside, the practice of polygamy is still been done, but the number is much lower than before. This research aims to provide understanding and insight to the community. The method used in this research is counseling, question and answer method. The most disadvantaged juridical implications of polygamous marriage are women and children, so that the children's rights are only recognized by their mother's side. In making a birth certificate, the child will only be recorded following the mother's name because the civil registration for children requires the existence of an official marriage certificate from the country. This affects the distribution of inheritance, where the child will face difficulty in obtaining inheritance rights, if the husband is an employee, then the wife does not get the husband's wedding allowance and pension benefit.

Keywords: juridical implications, polygamy

\section{PENDAHULUAN}

Secara umum poligami biasanya dipraktekkan oleh bangsa atau suku-suku nomaden yang hidup di alam yang keras dan gemar berperang. Di kalangan seperti ini poligami adalah sebuah kebutuhan karena kuat atau tidaknya suku mereka ditentukan oleh berapa banyak keturunan yang bisa dihasilkan terutama anak laki-laki karena laki-laki dalam komunitas ini dianggap sebagai komunitas militer.

Sedangkan perempuan hanya dianggap sebagai aset untuk memproduksi keturunan yang bahkan juga dijadikan sebagai salah satu harta rampasan perang bila suku itu kalah atau juga dijadikan alat pertukaran demi perdamaian antar suku. Di kalangan bangsa atau suku-suku yang menetap serta tidak banyak mengalami ancaman militer, poligami umumnya hanya dilakukan oleh kalangan tertentu saja yang biasanya kalangan elite dan berkuasa dimana praktek ini dijadikan sebagai salah satu simbol demi meningkatkan status dan sarana memamerkan kekayaan dan kekuasaannya. Sementara poligami di kalangan rakyat kebanyakan biasanya sangat jarang dilakukan. Hal ini juga terjadi di Indonesia dimana praktek poligami di kalangan rakyat kebanyakan tidak umum dilakukan.

Pada masa pra kemerdekaan sampai masa-masa awal kemerdekaan praktek poligami di Indonesia umumnya hanya dilakukan oleh 
kalangan elite masyarakat saja diantaranya kaum priyayi dan elite agama seperti para kyai.

Menurut pengamatan Koentjaraningrat (1986:19) ada perbedaan antara praktek poligami yang dilakukan kalangan priyayi dengan kalangan kyai yaitu kalangan priyayi yang umumnya berasal dari golongan Islam abangan biasanya menyatukan isteri-isterinya dalam satu rumah sementara kalangan kyai/santri sebagian besarnya membuatkan rumah yang terpisah-pisah bagi isteri-isterinya.

Memasuki era Indonesia modern praktek poligami semakin ditinggalkan oleh masyarakat, bahkan akhirnya menjadi sebuah praktek yang tidak lazim. Hal ini mengakibatkan pelaku poligami umumnya tidak melakukan praktek ini secara demonstratif seperti pada masa lalu. Praktek poligami dianggap sebagai praktek yang memalukan dan dapat merusak nama baik pelakunya. Sebagian besar perkawinan poligami di Indonesia, di era ini dilakukan secara sembunyisembunyi atau di bawah tangan terutama di kalangan menengah. $\mathrm{Di}$ kalangan santri tradisionalis terutama di pedesaan praktek poligami masih marak dilakukan tapi jumlahnya jauh lebih menurun daripada pada era sebelumnya. (Muthahhari, Murtadha. 2007: 32).

Poligami yang dilakukan di bawah tangan tidak menggunakan perjanjian yang kuat karena tidak tercatat secara hukum. Apabila ditinggalkan oleh suami, isteri tidak bisa menggugat suami. Kalaupun ingin menggugat cerai, penyelesaiannya diserahkan kepada pengadilan agama atau pengadilan negeri. Walaupun menimbulkan pro dan kontra dalam masyarakat, perkawinan di bawah tangan hingga kini masih banyak dilakukan. Bahkan sebenarnya tidak sedikit perempuan yang mengetahui "ruginya" jika melaksanakan perkawinan di bawah tangan, namun tetap saja banyak yang mau melakukannya dengan berbagai alasan. Perkawinan di bawah tangan atau yang umumnya disebut dengan nikah siri adalah menikah menurut ajaran agama atau hukum adat dan tidak merujuk pada hukum positif. Sehingga pernikahan itu tidak tercatat di Kantor Urusan Agama (KUA) maupun Kantor Catatan Sipil (KCS) (Hilman Hadikusuma. 2003:12)

Ada beberapa motivasi seseorang melakukan perkawinan di bawah tangan. Ada yang melakukan untuk poligami dengan tidak memberi tahu isteri pertama atau isteri yang sudah ada lebih dulu. Dan alasan lain adalah untuk penjajakan sebelum perkawinan yang tercatat dilakukan sehingga bila terjadi ketidakcocokan tidak menimbulkan konsekuensi hukum .(Ninuk mardiana Pambudy,2015:7). Perkawinan siri yang telah menjadi praktik umum di masyarakat membuka dan memudahkan laki-laki berpoligami tanpa melalui prosedur yang disyaratkan oleh Undang-Undang Nomor 1 Tahun 1974 tentang Perkawinan. (Herri Permana. 2010: 9). Walaupun, undang-undang ini pada prinsipnya menganut asas monogami.

Kegiatan pengabdian dilakukan di Desa Senggigi, Kecamatan Batu Layar, Lombok Barat, terletak di sebelah utara Kota Mataram Nusa Tenggara Barat, kurang lebih $10 \mathrm{~km}$ dari kota Mataram. Dalam perkembangan pariwisata tentunya akan berpengaruh terhadap lingkungan sekitar terutama terhadap penduduk setempat yang akan menimbulkan terjadinya pergeseran nilai-nilai yang berlaku dalam kehidupan masyarakat di sekitar daerah pariwisata Senggigi. Kontak sosial pasti akan terjadi diantara orangorang dari berbagai bahasa, ras, kepercayaan, paham politik dan tingkat perekonomian. Pariwisata memungkinkan diantara mereka untuk berdialog dan memungkinkan adanya hubungan antar pribadi yaitu mengadakan ikatan perkawinan di bawah tangan antara penduduk desa Senggigi atau bukan penduduk setempat dengan orang luar daerah Senggigi maupun dengan orang asing, tentunya dengan adanya perkembangan pariwisata di daerah tersebut mengakibatkan kemungkinan besar terjadi kontak sosial antara para wisatawan dengan masyarakat di sekitarnya. Kontak sosial yang terjadi mengandung makna rangkap yaitu: memberikan kesempatan kepada kedua belah pihak untuk saling mengenal kebudayaan masing-masing dan. memberikan kesempatan kedua belah pihak untuk mengenal sikap dasar yang dimiliki oleh masing-masing pihak.

Kegiatan ini bertujuan untuk memberikan pemahaman dan wawasan kepada masyarakat setempat bahwa perkawinan poligami di bawah tangan seharusnya tidak boleh terjadi karena akan mengakibatkan kerugian pada masyarakat terutama kaum wanita anak-anak karena tidak memiliki kekuatan hukum.

\section{METODE PELAKSANAAN}

Metode yang digunakan dalam pelaksanaan pengabdian pada masyarakat ini adalah dengan penyuluhan, selain dengan metode tersebut juga dipergunakan metode tanya jawab dari khalayak sasaran yaitu warga masyarakat Desa Senggigi.

\section{HASIL DAN PEMBAHASAN}

Pada prinsipnya Undang-Undang No. 1 Tahun 1974 menganut asas monogami. Namun undang-undang ini tidak menutup kemungkinan begitu saja bagi mereka yang ingin berpoligami sepanjang agama/kepercayaan mengijinkan serta 
dapat memenuhi persyaratan-persyaratan yang ditentukan oleh undang-undang ini.

Ketentuan tentang poligami tersebut ditegaskan dalam Pasal 3 ayat 2 Undang-Undang No. 1 Tahun 1974, yang menyatakan: "Pengadilan dapat memberi ijin kepada seorang suami untuk beristeri lebih dari seorang apabila dikehendaki oleh pihak-pihak yang bersangkutan."

Mengenai persyaratan untuk berpoligami bagi seorang pria, ketentuannya tersebut dalam Pasal 3 ayat 2 beserta penjelasannya sebagai berikut :

1. Harus ada ijin dari Pengadilan;

2. Bila dikehendaki oleh yang bersangkutan;

3. Hukum dan agama yang bersangkutan mengijinkannya, artinya tidak ada larangan dalam hal ini.

Dalam hal seorang suami yang akan beristeri lebih dari seorang harus mendapat ijin dari pengadilan, khusus bagi yang beragama Islam ijin itu harus diajukan ke Pengadilan Agama. Untuk mendapat ijin dari Pengadilan harus memenuhi beberapa syarat tertentu dan disertai alasanalasan yang dibenarkan. Tentang hal ini lebih lanjut diatur dalam Pasal 4 dan Pasal 5 yang pada dasarnya adalah sebagai berikut :

1. Harus mengajukan permohonan kepada Pengadilan di daerah tempat tinggalnya (Pasal 4 ayat 1$)$.

2. Pengadilan hanya akan memberi ijin apabila permohonan itu didasarkan pada alasan yang dibenarkan, seperti yang ditentukan dalam Pasal 4 ayat 2, sebagai berikut :
a) Isteri tidak dapat menjalankan kewajibannya sebagai isteri.
b) Isteri mendapat cacat badan atau penyakit yang tidak dapat disembuhkan.
c) Apabila isteri tidak memperoleh keturunan

3. Untuk dapat mengajukan permohonan kepada Pengadilan harus dipenuhi syarat-syarat tertentu yang ditentukan dalam Pasal 5 ayat 1 , yaitu :

a) Adanya persetujuan dari isteri/isteri-isteri yang terdahulu.

b) Adanya kepastian bahwa suami akan mampu menjamin keperluan-keperluan hidup isteri-isteri dan anak-anak mereka.

c) Adanya jaminan bahwa suami akan berlaku adil terhadap isteri-isteri dan anakanak mereka.

Dalam hal pelaksanaan perkawinan poligami, langkah-langkah yang harus ditempuh diatur dalam Bab VIII Peraturan Pemerintah No. 9 Tahun 1975, yaitu :

1. Apabila seorang suami bermaksud untuk beristeri lebih dari seorang maka ia wajib mengajukan permohonan secara tertulis kepada Pengadilan (Pasal 40).

2. Pengadilan kemudian memeriksa apakah permohonan tersebut telah memenuhi syaratsyarat yang diatur dalam Undang-Undang No. 1 Tahun 1974, pemeriksaan dilakukan selambat-lambatnya 30 hari setelah diterimanya surat permohonan (Pasal 41 dan 42).

3. Apabila Pengadilan berpendapat bahwa pemohon telah memenuhi syarat-syarat yang ditentukan, maka Pengadilan memberikan putusan berupa ijin untuk melaksanakan poligami.

Perkawinan di bawah tangan atau juga dikenal dengan berbagai istilah seperti "kawin siri" atau "nikah siri", adalah perkawinan yang dilakukan berdasarkan aturan agama atau adat istiadat tetapi tidak dicatatkan di negara. Pencatatan bagi yang beragama Islam dilakukan di Kantor Urusan Agama (KUA), dan bagi non-Islam di Kantor Catatan Sipil. Perkawinan siri yang telah menjadi praktik umum di masyarakat membuka peluang dan memudahkan laki-laki berpoligami tanpa melalui prosedur yang disyaratkan,

Implikasi yuridis dari perkawinan poligami di bawah tangan yang ditemukan pada masyarakat tempat diadakan pengabdian pada masyarakat ini tanpa melalui prosedur yang telah ditentukan dalam peraturan yang ada sehingga banyak terjadinya perkawinan dibawah tangan, dalam banyak kasus yang ditemukan yang paling dirugikan adalah perempuan dan anak-anak. Perkawinan yang tidak dicatatkan, misalnya, bila mendapatkan keturunan, maka anak tersebut hanya diakui hak-haknya dari pihak ibu. Dalam pembuatan akta kelahiran, misalnya, anak hanya akan dicatat mengikuti nama ibu karena catatan sipil untuk kelahiran anak mengisyaratkan adanya surat nikah resmi dari negara. Hal ini berimbas pada pembagian harta warisan, dimana sang anak akan kesulitan mendapatkan hak warisnya. Lebih dari itu, isteri tidak memperoleh tunjangan apabila suami meninggal, misalnya menerima asuransi. Dan, apabila suami sebagai pegawai, maka isteri tidak memperoleh tunjangan perkawinan dan tunjangan pensiun si suami.

\section{SIMPULAN DAN SARAN Simpulan}

Implikasi yuridis dari perkawinan poligami di bawah tangan dalam banyak kasus yang paling dirugikan adalah perempuan dan anak-anak. Perkawinan yang tidak dicatatkan, misalnya, bila mendapatkan keturunan, maka anak tersebut hanya diakui hak-haknya dari pihak ibu. Dalam pembuatan akta kelahiran, misalnya, anak hanya 
akan dicatat mengikuti nama ibu karena catatan sipil untuk kelahiran anak mengisyaratkan adanya surat nikah resmi dari negara.

Hal ini berimbas pada pembagian harta warisan, dimana sang anak akan kesulitan mendapatkan hak warisnya. Lebih dari itu, isteri tidak memperoleh tunjangan apabila suami meninggal, misalnya menerima asuransi. Dan, apabila suami sebagai pegawai, maka isteri tidak memperoleh tunjangan perkawinan dan tunjangan pensiun si suami.

\section{Saran}

Saran yang dapat diberikan sehubungan dengan kegiatan pengabdian ini adalah sebagai berikut:

1. Perlu adanya sosialisasi kepada masyarakat bahwa dalam pergaulan bermasyarakat hendaknya memperhatikan norma yang berlaku.

2. jika hendak melakukan perkawinan seharusnya berhati-hati jangan sampai memilih seorang laki-laki yang sudah memiliki istri.

3. Masyarakat diharapkan memiliki wawasan dan kemampuan untuk mengetahui terlebih dahulu sisi positip dan negatipnya akibat dari perkawinan poligami.

\section{DAFTAR RUJUKAN}

Hadikusuma, Hilman. 2003. Hukum Perkawinan Indonesia Menurut Perundang-undangan, Hukum Adat, Hukum Agama. Bandung : Mandar Maju.

Muthahhari, Murtadha. 2007. Duduk Perkara Poligami. Jakarta : Ikrar Mandiriabadi.

Koentjaraningrat, 1986. Pengantar IImu Antropologi. Jakarta:Aksara Baru.

Pambudy, Ninuk mardiana. 2015. Undang-Undang Perkawinan dan Poligami. www.kompas.com

Permana, Herri. 2010. Poligami Dalam Sistem Hukum di Indonesia. www.mailarchive.com

Republik Indonesia, Kitab Undang-undang Hukum perdata

Republik Indonesia, Undang-Undang No. 1 Tahun 1974 tentang Perkawinan. LN No. 1 Tahun 1974. TLN No. 3019.

Republik Indonesia, Peraturan Pemerintah No 9 Tahun 1975 tentang Pelaksanaan UU No. 1 Tahun 1974. 